\title{
НАУЧНЫЕ СОБЫТИЯ
}

\section{Проблемы труда и занятости молодежи: новые вызовы и перспективы}

\author{
А. С. Гонашвили, С. С. Старовойтова \\ Санкт-Петербургский государственный университет, \\ Российская Федерация, 199034, Санкт-Петербург, Университетская наб., 7-9
}

Для цитирования: Гонашвили А. С., Старовойтова С. С. Проблемы труда и занятости молодежи: новые вызовы и перспективы // Вестник Санкт-Петербургского университета. Социология. 2018. Т. 11. Вып. 3. С. 393-397. https://doi.org/10.21638/spbu12.2018.309

28 февраля состоялся второй Петербургский международный молодежный форум труда. Санкт-Петербургский международный молодежный форум труда (ПММФТ) - первая международная площадка, созданная для дискуссий представителей молодого поколения по широкому спектру волнующих их вопросов в сфере труда, занятости, человеческого капитала, трудовой мобильности, кадрового менеджмента, а также для их диалога со всеми заинтересованными сторонами - государством, бизнесом, НКО и учеными. Цель форума - сателлита Петербургского международного форума труда - стать ведущей международной площадкой для регулярного диалога по современным проблемам труда и новым вызовам в сфере занятости молодежи [1].

В работе форума приняли участие представители 79 вузов, двух ссузов из 49 городов и 13 стран. На пяти площадках проведено 35 научных, прикладных и интерактивных мероприятий, в том числе впервые организован «День карьеры» как интерактивная площадка для выстраивания эффективного взаимодействия между работодателями и студентами. Форум посетили 2500 человек, 700 из них стали активными участниками его мероприятий.

В рамках второго Петербургского международного молодежного форума труда работала научная конференция, на которой продолжилось обсуждение проблем, поднятых на конференции, проходившей в рамках первого Санкт-Петербургского форума труда [2]. Конференция объединила на своей площадке большое количество представителей молодого поколения из разных уголков России, а также из стран ближнего зарубежья. Участниками конференции стали молодые люди, интересующиеся теоретическими вопросами и практическими решениями современных проблем труда среди молодежи. В рамках конференции была организована секция «Проблемы труда и занятости: новые вызовы и перспективы».

Работа секции способствовала выявлению и анализу основных проблем, с которыми сталкивается молодежь, выходя на рынок труда. Модераторами выступили: Любовь Александровна Лебединцева, доцент кафедры экономической социологии Санкт-Петербургского

(c) Санкт-Петербургский государственный университет, 2018 


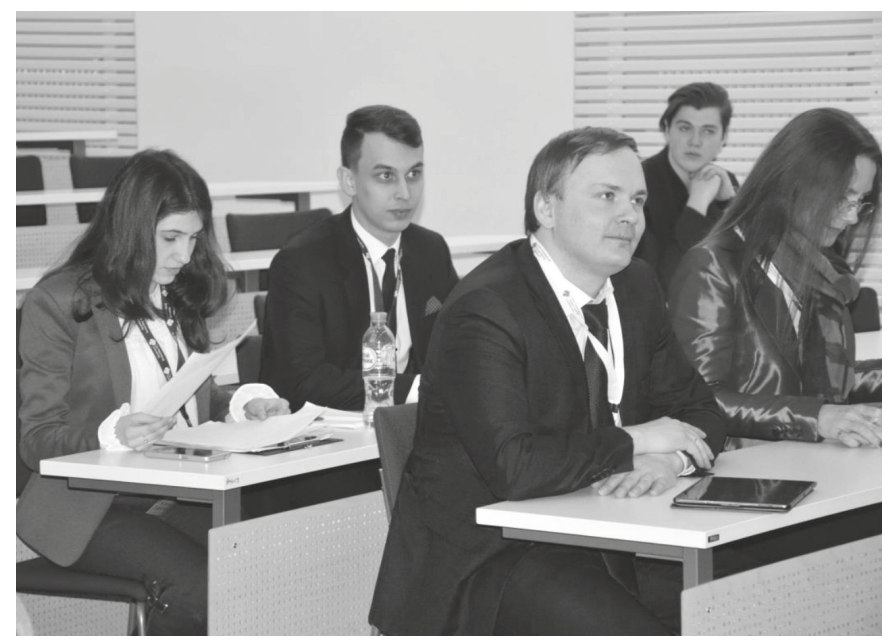

Puc. 1. Работа секции «Проблемы труда и занятости: новые вызовы и перспективы»

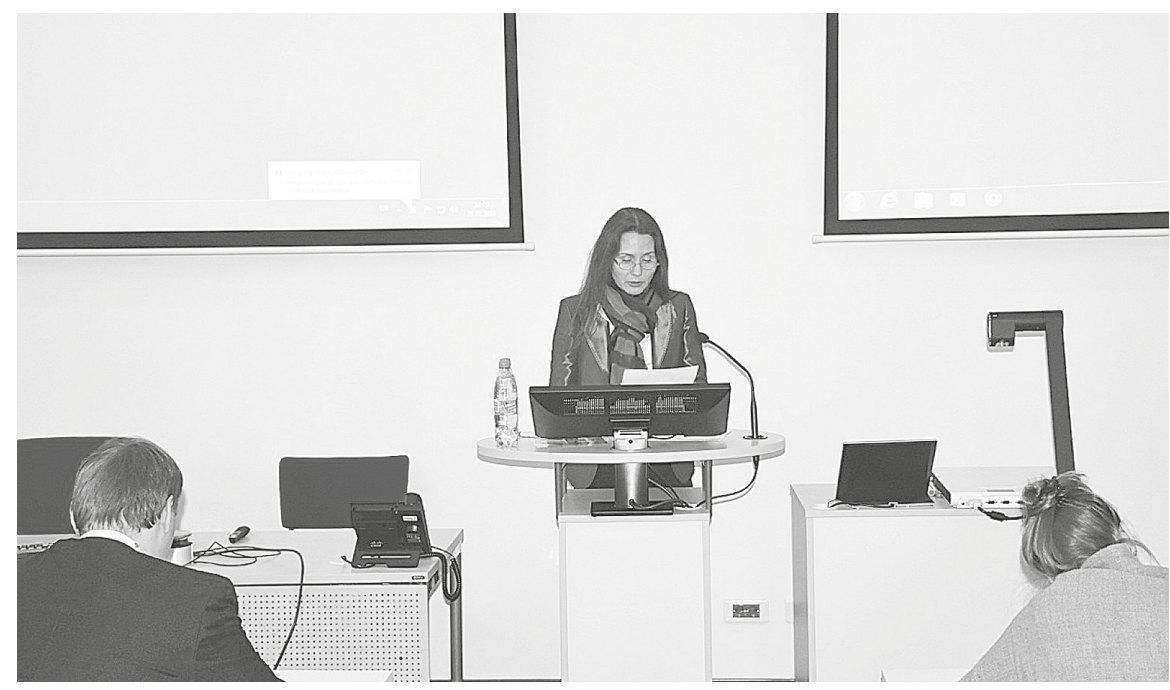

Рuс. 2. Вступительное слово Л. А. Лебединцевой

государственного университета, доктор социологических наук, и Игорь Андреевич Мурашев, заместитель председателя Комитета государственной службы и кадровой политики администрации губернатора Санкт-Петербурга, начальник отдела оценки и кадровых резервов.

На секции с докладами выступили восемь участников. В докладе Ольги Воробьевой, бакалаврианта факультета международных отношений Санкт-Петербургского государственного университета, были охарактеризованы проблемы и возможности трудоустройства молодых людей в сфере медиа. Докладчик рассказала об основных тенденциях, которые характерны для рынка труда молодых специалистов. Статистические данные, по мнению О. Воробьевой, свидетельствуют о неблагоприятной ситуации в сфере молодежной занятости: в 2017 г. доля молодежи в общей численности безработных в мире составила более 35 \% (70,9 млн молодых людей) [3]. По прогнозам Международной организации труда, в 2018 г. уровень молодежной безработицы вырастет: 71,1 млн молодых людей окажутся без работы. Одной из проблем, за- 


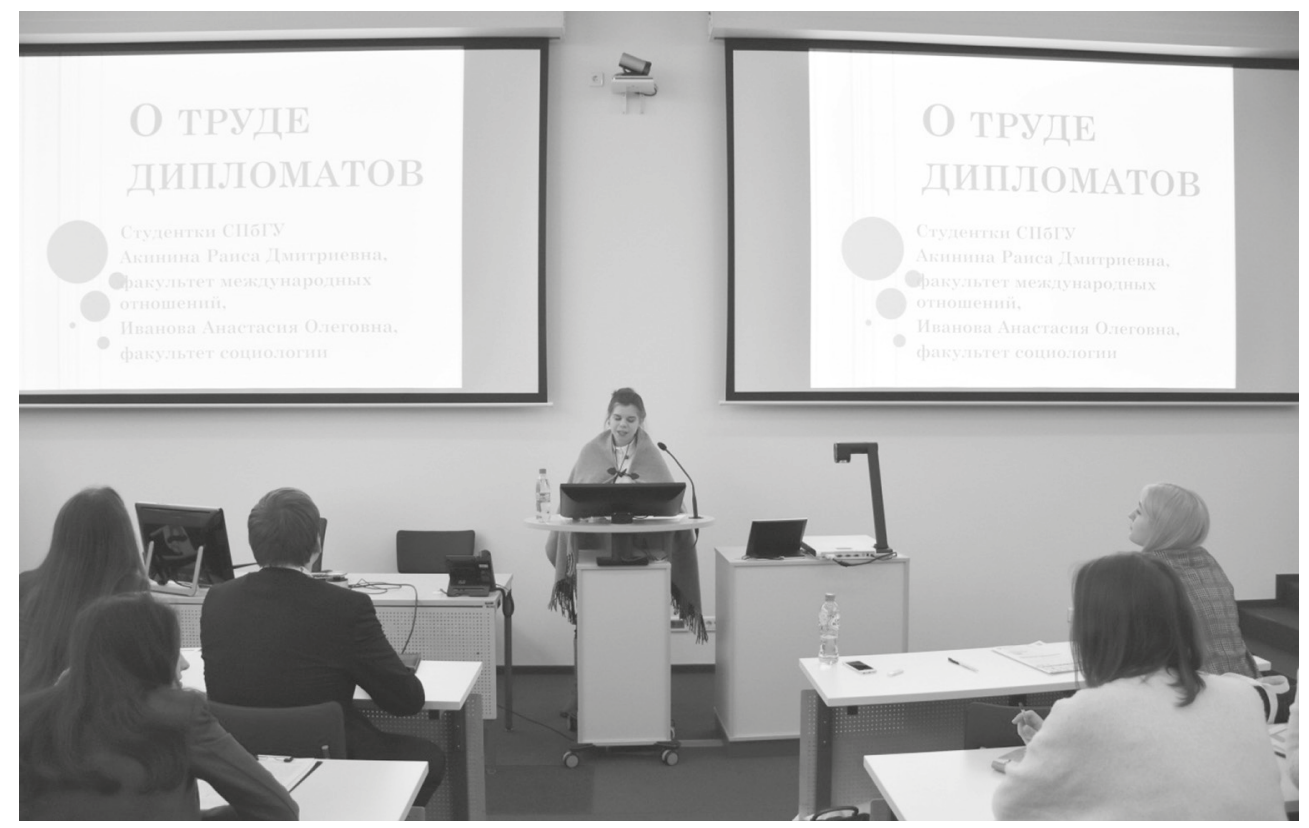

Puc. 3. Доклад Раисы Акининой и Анастасии Ивановой

тронутых в докладе О.Воробьевой, стали трудности, с которыми сталкиваются выпускники при трудоустройстве в организации медиасферы. Причина этих трудностей, по мнению докладчика, заключается в неналаженности коммуникации между организациями медиасферы и университетами. В ходе дискуссии участники пришли к выводу, что выпускники вузов, стремящиеся реализовать себя в данной сфере, не всегда обладают необходимыми возможностями и компетенциями для достижения поставленной цели, и им очень нужна поддержка вузов.

Проблемам трудоустройства молодых специалистов в сфере медиа был посвящен также доклад студентки Санкт-Петербургского государственного университета по направлению «Юриспруденция» Антонины Болотиной, которая акцентировала внимание на необходимости налаживания более тесного контакта между вузами и работодателями. Возможность тесного взаимодействия с работодателем в период обучения, по мнению А. Болотиной, поможет студентам преодолеть страх при трудоустройстве по профилю подготовки. При этом важным плюсом является то, что, зарекомендовав себя положительно, студент будет обеспечен работой, уровень безработицы снизится, а грамотных и компетентных специалистов станет значительно больше.

В докладе студентов Санкт-Петербургского государственного университета Раисы Акининой и Анастасии Ивановой рассматривались особенности труда дипломатических работников. Были выделены три основных компонента профессиональной деятельности дипломатов: 1) высокий уровень самоконтроля; 2) коммуникативная компетентность; 3) развитое логическое мышление. Выступление студентов вызвало большой интерес у слушателей.

В докладе магистрантов Санкт-Петербургского государственного университета Снежаны Старовойтовой и Александра Гонашвили рассматривались не только вопросы умственного труда, но и трактовка самой категории «умственный труд». В выступлении отмечалось, что предложенные в 1950-е годы подходы к определению умственного труда не соответствуют современным исследовательским тенденциям.

Доклад студентки магистерской программы «Управление человеческими ресурсами» Санкт-Петербургского государственного университета Варвары Морозовой на тему «Обуче- 
ние сотрудников на рабочих местах» также вызвал интерес у участников секции. По мнению В. Морозовой, обучение на рабочем месте создает фундамент не только для развития персонала, но также для развития бизнеса и позитивных изменений на рынке труда. Обучение на рабочем месте является фактором снижения издержек производства, роста производительности труда и повышения инновационной активности работников.

Не оставило равнодушным аудиторию и выступление магистранта Санкт-Петербургского государственного университета Яны Седунковой на тему «Профессиональные предпочтения учащихся среднеобразовательных школ Санкт-Петербурга в условиях трансформации рынка труда». Докладчик представила авторский проект профессионально-личностного самоопределения школьников. По мнению Я.Седунковой, сегодня назрела необходимость создания модели «умной и прозрачной профориентации», которая соединит усилия органов государственной власти, школы, родителей, обучающихся, работодателей и создаст надежную основу для развития экономического потенциала страны во всех областях, особенно в условиях импортозамещения. В докладе подчеркивалась особая актуальность разработки индивидуальных программ профориентации школьников с учетом современных тенденций рынка труда.

Студент Российского государственного гидрометеорологического университета Даниил Сергеев представил авторский проект по координации деятельности, связанной с трудоустройством выпускников школ и вузов. Основная идея - создание координационного центра, оказывающего помощь студентам и школьникам в поиске стажировок и практик, а также трудоустройства.

Завершил работу секции доклад студентки факультета искусств Санкт-Петербургского государственного университета Татьяны Никулиной, посвященный развитию креативной индустрии и преимуществам работы в ней. Студентка подчеркнула, что креативные индустрии являются привлекательной для молодежи сферой занятости, однако работа в этой сфере сопряжена с рядом проблем как финансового, так и юридически-правового характера. Важно изменить отношение к креативным индустриям, рассматривать их как сектор инновационной экономики. В докладе отмечалось, что креативные индустрии нуждаются в финансовой и законодательной поддержке, в формировании системы статистического учета и отчетности.

В целом работа секции «Проблемы труда и занятости: новые вызовы и перспективы» вызвала большой интерес у молодежи. Дискуссии, которые возникали в ходе выступлений докладчиков, свидетельствует о том, что проблемы труда и занятости выпускников чрезвычайно актуальны для молодого поколения. Второй Петербургский международный молодежный форум труда 2018 г. и конференция, проходившая в рамках данного форума, показали, что исследования в области труда требуют междисциплинарного подхода. В его рамках экономика и социология могут составить теоретическое ядро, формирующее понимание значения, роли и функций труда в обществе.

Анализ выступлений на секции продемонстрировал высокий интерес молодых исследователей к обсуждению путей совершенствования рынка труда и трудовых практик, а также к поиску путей улучшения взаимодействия работодателей с вузами. Все участники секции «Проблемы труда и занятости: новые вызовы и перспективы» - социологи, экономисты, юристы, международники - ждут большего притока участников на очередном молодежном форуме труда.

\section{Литература}

1. II Петербургский международный молодежный форум труда. URL: http://piylf.spbu.ru (дата обращения: 22.03.2018).

2. Карапетян Р. В., Никифорова О.А., Таранова О. А. Международная научная конференция «Труд и общество в реалиях XXI века» // Журнал социологии и социальной антропологии. 2017. 20(2). С. 197-202.

3. Международная организация труда (ILO). URL: http://www.ilo.org/moscow/news/WCMS_600703/ lang--ru/index.htm (дата обращения: 22.03.2018). 
Контактная информация:

Гонашвили Александр Сергеевич - магистрант; gon.01.07.94@yandex.ru

Старовойтова Снежана Сергеевна - магистрант; snezka370@yandex.ru

For citation: Gonashvili A.S., Starovoitova S. S. Problems of labor and youth employment: New challenges and prospects. Vestnik of Saint Petersburg University. Sociology, 2018, vol. 11, issue 3, pp. 393397. https://doi.org/10.21638/spbu12.2018.309 (In Russian)

\section{References}

1. II Peterburgskii mezhdunarodnyi molodezhnyi forum truda [St. Petersburg international youth labour forum]. Available at: http://piylf.spbu.ru (accessed: 22.03.2018). (In Russian)

2. Karapetian R. V., Nikiforova O.A., Taranova O.A. Mezhdunarodnaia nauchnaia konferentsiia «Trud i obshchestvo v realiiakh XXI veka» [International scientific conference "Labor and society in realities of the XXI century"]. Zhurnal sotsiologii i sotsial'noi antropologii, 2017, no. 20(2), pp. 197-202. (In Russian)

3. International Labour Organization (ILO). Available at: http://www.ilo.org/moscow/news/ WCMS_597065/lang--en/index.htm (accessed: 22.03.2018).

Author's information:

Aleksandr S. Gonashvili — master student; gon.01.07.94@yandex.ru

Snezhana S. Starovoitova - master; snezka370@yandex.ru 